\title{
Child-Management Techniques. Are There Differences in the Way Female and Male Pediatric Dentists in Israel Practice?
}

\author{
Benjamin PERETZ \\ Hagit GLAICHER \\ Diana RAM \\ Department of Pediatric Dentistry, Hebrew University Hadassah School of Dental Medicine, Jerusalem, Israel
}

\begin{abstract}
The purpose of this study was to assess differences in the management techniques used by Israeli female and male pediatric dentists. All 112 participants of the meeting of the Israeli Society of Dentistry for Children that was held in February 1999 received a questionnaire which sought information regarding age, sex, behavioral and pharmacological methods used to treat children, having a course in nitrous oxide, general anesthesia, and feelings towards pediatric patients. No differences between female and male dentists were found regarding most management techniques. The majority of dentists used tell-show-do, and gave presents at the end of the appointments. Hypnosis was the least used technique. Papoose board was more prevalent among male dentists than among female dentists. Most dentists reported having the parents present during treatment, and more male dentists used their assistance when restraint was needed. General anesthesia was significantly more prevalent among males than among females $(p=0.01)$. One-third of the dentists reported feeling aggression toward the pediatric patient. Although not statistically significant, more female dentists reported about feeling aggression than male dentists. Most dentists felt authority towards the pediatric patient. Our findings imply that female and male dentists use similar management techniques when treating children.
\end{abstract}

Key Words: child-management techniques, pediatric dentists.

\section{INTRODUCTION}

Social changes are often reflected in professional life as well as in family life. One of the major social changes taking place in the last two decades is the role of women in society. Women are increasingly taking on traditional 'male' roles in the family cell as well as in professional life, while the opposite is observed among men $(1,2)$. This trend has been increasingly noted in the dental profession. Furthermore, the role of women as leaders has undergone considerable review in recent years, both outside and within the dental profession. Growing awareness of gender as an issue in leadership has focused attention on leadership styles and qualities with particular emphasis on the differences between male and female approaches (3).

Among the dental specialties, it is accepted that pediatric dentistry has the highest representation of women compared to other advanced dental areas and predoctoral programs $(4,5)$. Greater female representation in pediatric dentistry has been attributed to a traditional state of mind that treating a child requires qualities such as tenderness and empathy, or caring, that women may possess more than men (6).

There are nearly 7000 dentists in Israel (7) where, like in other countries, female representation in undergraduate studies in dentistry has been constantly increasing, and is now about $50 \%$ of the students (8). Moreover, among 16 candidates for post-graduate training in pediatric dentistry last year at the Hebrew University Hadassah School of Dental Medicine, 10 were females.

The Israeli Society of Dentistry for Children accepts the membership of specialists in pediatric dentistry, as well as general practitioners whose main 
interest is children. There are 215 members of the society, among whom 53 are registered specialists and the remaining 162 are general practitioners. Non-members of the Society attend meetings in which pediatric dentists and general practitioners participate.

A recent survey among members of the Israeli Society of Dentistry for Children demonstrated that, basically, there were no major differences in the educational background and practice arrangements between male and female pediatric dentists (9). The authors concluded that pediatric dentistry in Israel appears to be a profession in which both sexes have equal opportunity.

Research on differences between male and female dentists in terms of the use of management techniques has rarely been published. An Australian survey of strategies used by dentists to manage children with behavioral problems revealed that female dentists were less likely to use aversive techniques $(10,11)$.

It is important to know about possible differences in the way female and male pediatric dentists in Israel practice in a specialty where potentially equal opportunities for women and men exist. The use of management techniques may impact differently on dental care service. Therefore, the purpose of the present study was to assess differences in the management techniques used by Israeli female and male pediatric dentists.

\section{MATERIAL AND METHODS}

All 112 participants of the meeting of the Israeli Society of Dentistry for Children that was held in February 1999 received, upon registration, a questionnaire to complete during the meeting and to return upon leaving the hall. The questionnaire sought information regarding age, sex, behavioral methods used to treat children (9 items: tell-show-do, presents given, modeling, hypnosis, voice control, papoose board, handover-mouth exercise, parents present during treatment, parental restraint), pharmacological methods (4 items: nitrous oxide, premedication, course in the use of nitrous oxide, general anesthesia), and feelings towards pediatric patients ( 2 items: aggression, authority).

The questions were developed by the authors and included possible variations that seemed likely to yield information of relevance to the study aims. The questions were based on the authors', as well as other colleagues', experience in Israel and worldwide. The questionnaire was tested in a pilot study among 10 dentists (not included in the present study) to insure the clarity of the questions.

Data were analyzed using descriptive statistics. Chi-square analysis was performed for the information obtained for the various parameters as recommended in other similar studies. Level of significance was set at $\mathrm{p}<0.05$.

Table 1. Behavioral methods used by Israeli pediatric dentists.

\begin{tabular}{|c|c|c|c|}
\hline & Males (27) & Females (43) & Total (70) \\
\hline \multicolumn{4}{|c|}{ Tell-Show-Do } \\
\hline Yes & $25(96 \%)$ & $40(98 \%)$ & $65(97 \%)$ \\
\hline \multirow[t]{2}{*}{ No } & $1(4 \%)$ & $1(2 \%)$ & $2(3 \%)$ \\
\hline & 26 & 41 & 67 \\
\hline \multicolumn{4}{|c|}{ Presents } \\
\hline Yes & $22(81 \%)$ & $37(86 \%)$ & $59(84 \%)$ \\
\hline \multirow[t]{2}{*}{ No } & $5(19 \%)$ & $6(14 \%)$ & $11(16 \%)$ \\
\hline & 27 & 43 & 70 \\
\hline \multicolumn{4}{|c|}{ Modeling } \\
\hline Yes & $18(78 \%)$ & $31(90 \%)$ & $49(86 \%)$ \\
\hline \multirow[t]{2}{*}{ No } & $5(22 \%)$ & $3(10 \%)$ & $8(14 \%)$ \\
\hline & 23 & 34 & 57 \\
\hline \multicolumn{4}{|c|}{ Hypnosis } \\
\hline Yes & $8(34 \%)$ & $10(29 \%)$ & $6(10 \%)$ \\
\hline \multirow[t]{2}{*}{ No } & $15(66 \%)$ & $25(71 \%)$ & $52(90 \%)$ \\
\hline & 23 & 35 & 58 \\
\hline \multicolumn{4}{|c|}{ Voice control } \\
\hline Yes & $22(85 \%)$ & $34(85 \%)$ & $56(85 \%)$ \\
\hline \multirow[t]{2}{*}{ No } & $4(15 \%)$ & $6(15 \%)$ & $10(15 \%)$ \\
\hline & 26 & 40 & 66 \\
\hline \multicolumn{4}{|c|}{ Papoose board } \\
\hline Yes & $11(44 \%)$ & $10(28 \%)$ & $21(34 \%)$ \\
\hline \multirow[t]{2}{*}{ No } & $14(56 \%)$ & $26(72 \%)$ & $40(66 \%)$ \\
\hline & 25 & 36 & 61 \\
\hline \multicolumn{4}{|c|}{ Parents present } \\
\hline Yes & $24(89 \%)$ & $39(95 \%)$ & $63(93 \%)$ \\
\hline \multirow[t]{2}{*}{ No } & $3(11 \%)$ & $2(5 \%)$ & $5(7 \%)$ \\
\hline & 27 & 41 & 68 \\
\hline \multicolumn{4}{|c|}{ Parental restraint } \\
\hline Yes & $18(72 \%)$ & $20(57 \%)$ & $38(63 \%)$ \\
\hline \multirow[t]{2}{*}{ No } & $7(28 \%)$ & $15(43 \%)$ & $22(37 \%)$ \\
\hline & 25 & 35 & 60 \\
\hline \multicolumn{4}{|c|}{ Hand-over-mouth exercise } \\
\hline Yes & $7(30 \%)$ & $9(26 \%)$ & $16(28 \%)$ \\
\hline \multirow[t]{2}{*}{ No } & $16(70 \%)$ & $26(26 \%)$ & $42(72 \%)$ \\
\hline & 23 & 35 & 58 \\
\hline
\end{tabular}

No statistically significant differences were found (chi-square test). 


\section{RESULTS}

Of the 112 dentists who attended the meeting of the Israeli Society of Dentistry for Children, 70 completed questionnaires were returned, 27 by male dentists, 43 by female dentists. The number of respondents to the various items ranged between 21 to 27 among male dentists, and 34 to 43 among female dentists.

Table 1 shows the behavioral methods used by Israeli pediatric dentists. No significant gender difference was found. The vast majority of dentists used tell-show-do, and most gave presents at the end of the dental appointment. Hypnosis was the least used behavioral technique. Papoose board was used more among male dentists than among female dentists (44\% and $28 \%$, respectively). Most dentists reported having the parents present in the room during treatment, and more male dentists used their assistance when restraint was needed. Hand-over-mouth exercise was used by $28 \%$ of the dentists ( $30 \%$ among males, $26 \%$ among females).

Table 2 shows the pharmacological methods used by Israeli pediatric dentists. General anesthesia was significantly more prevalent among male dentists than female dentists $(56 \%$ and $26 \%$, respectively, $\mathrm{p}=$ 0.01 ). No significant difference was observed between male and female dentists with respect to the use of

Table 2. Pharmacological methods used by Israeli pediatric dentists.

\begin{tabular}{|c|c|c|c|c|}
\hline & Males (27) & Females (43) & Total (70) & $\mathrm{P}$ \\
\hline \multicolumn{5}{|c|}{ Nitrous oxide } \\
\hline Yes & $21(78 \%)$ & $33(79 \%)$ & $54(78 \%)$ & \\
\hline \multirow[t]{2}{*}{ No } & $6(22 \%)$ & $9(21 \%)$ & $15(22 \%)$ & NS \\
\hline & 27 & 42 & 69 & \\
\hline \multicolumn{5}{|c|}{ Premedication and $\mathrm{N}_{2} \mathrm{O}$} \\
\hline Yes & $17(68 \%)$ & $19(53 \%)$ & $36(59 \%)$ & \\
\hline \multirow[t]{2}{*}{ No } & $8(32 \%)$ & $17(47 \%)$ & $25(41 \%)$ & NS \\
\hline & 25 & 36 & 61 & \\
\hline \multicolumn{5}{|c|}{ Course in $\mathrm{N}_{2} \mathrm{O}$} \\
\hline Yes & $22(85 \%)$ & $33(79 \%)$ & $55(82 \%)$ & \\
\hline \multirow[t]{2}{*}{ No } & $4(15 \%)$ & $8(21 \%)$ & $12(18 \%)$ & NS \\
\hline & 26 & 41 & 67 & \\
\hline \multicolumn{5}{|c|}{ General anesthesia } \\
\hline Yes & $14(56 \%)$ & $11(26 \%)$ & $25(37 \%)$ & \\
\hline \multirow[t]{2}{*}{ No } & $11(44 \%)$ & $31(74 \%)$ & $42(63 \%)$ & 0.01 \\
\hline & 25 & 42 & 67 & \\
\hline
\end{tabular}

Chi-square test. nitrous oxide or premedication. Most dentists used nitrous oxide and had undergone a course on the subject, whereas dentists used premedication to a lesser degree.

Table 3 reports dentists' feelings while treating children. One third of the dentists $(35 \%)$ reported a feeling of aggression toward the pediatric patient. Although not statistically significant, more female dentists reported aggression than male dentists (44\% and $22 \%$, respectively). Most dentists felt authority towards the pediatric patient.

\section{DISCUSSION}

The rationale underlying the decision to conduct the study was to obtain information about the management techniques of male and female dentists who treat children, and to provide some insight into their ways of work.

With regard to behavior management techniques, our findings show that the vast majority of dentists use tell-show-do (97\%), followed by modeling, voice control, parental restraint, papoose board, hand-over-mouth exercise and hypnosis. Modeling was more prevalent among women, parental restraint and papoose board were more prevalent among men. These findings are in agreement with previous reports that female dentists were less likely to use aversive techniques $(10,11)$. However, no difference was found between males and females with regard to voice control, which also may be perceived as an aversive technique. Interestingly, handover-mouth exercise was still used by $16 \%$ of respondents, with no difference between the sexes.

Table 3. Dentists' feelings while treating children.

\begin{tabular}{lcll}
\hline & Males (27) & Females (43) & Total (70) \\
\hline Aggression & & & \\
Yes & $5(22 \%)$ & $17(44 \%)$ & $22(35 \%)$ \\
No & $17(78 \%)$ & $24(56 \%)$ & $44(65 \%)$ \\
& 22 & 41 & 66 \\
Authority & & & $57(93 \%)$ \\
Yes & $19(90 \%)$ & $38(95 \%)$ & $4(7 \%)$ \\
No & $2(10 \%)$ & $2(5 \%)$ & 61 \\
& 21 & 40 & \\
\hline
\end{tabular}

There were no statistically significant differences (chi-square test). 
Only $10 \%$ of respondents used hypnosis. This may be explained by the fact that the law in Israel permits only officially trained and registered dentists in hypnosis to use this method.

The prevalence of techniques used is understandable because tell-show-do is the easiest, mildest and most logical technique for the dentist to use. Also, this hierarchy of techniques seems to confirm parents' acceptance of techniques, with the mildest technique being the most acceptable (12-14).

The finding that $93 \%$ of respondents allow parents to be present during treatment is in accordance with the results of Peretz and Zadik (15), who found that most parents expressed the wish to be with their children, and were willing to assist the dentist if behavioral problems with the child arose.

With regard to pharmacological methods, most dentists use nitrous oxide for sedation with no difference between females and males having had a formal course in its use. No explanation can be provided for the finding that significantly more males used general anesthesia.

Our findings show that most dentists felt authority towards the pediatric patient. These findings, reflecting the subjective feelings of the dentists, must be interpreted with caution because they were obtained from two questions only. Glasrud (16) concluded that authoritarian attitudes and measures of productivity were more likely to be correlated with more frequent use of physical restraint. Moreover, one-third of dentists felt aggression towards patients. Twice as many female dentists reported having this feeling. It may be that women can more easily admit their feelings than men whereas men may not acknowledge the feeling. However, this finding shows that although the feeling of aggression is more prevalent among women, the techniques used were to the same degree, or somewhat less, aversive than those of men.

Our findings suggest that women use similar management techniques to men when treating pediatric dental patients, in a specialty that shows great equality of opportunity between the sexes.

There are several limitations to our study. The first is the small cluster sample, which may lead to some bias in interpreting the findings. However, this was caused by practical constraints: the respondents included specialists and non-specialists who attended a meeting of the Israel Society of Dentistry for Children, and, of course, may not represent the general population of dentists in Israel. The second is the nature of the sample. Obviously, dentists who participate in scientific events may have a greater involvement in the profession and seek to remain up-to-date on the latest techniques. The third limitation is the locality of the surveyed population. Although the setting is purely local, the results may bear a global interest, since similar trends have been reported internationally.

\section{RESUMO}

O objetivo desse estudo foi determinar diferenças em técnicas de manuseio de pacientes usadas por odontopediatras do sexo feminino e masculino. Todos os participantes do Congresso da Sociedade Israelense de Odontopediatria ocorrido em fevereiro de 1999 receberam um questionário consernente à idade, sexo, comportamento, métodos farmacológicos empregados para o tratamento de crianças, um curso de óxido nítrico, anestesia geral, e sentimentos frente ao paciente pediátrico. Nenhuma diferença entre profissionais do sexo feminino e masculino foram encontradas quanto às técnicas de manuseio. A maioria dos dentistas utilizaram-se da técnica falar-mostrar-fazer e presentearam o paciente no final da sessão. A hipnose foi a técnica menos utilizada. O uso do papoose board foi maior entre dentistas do sexo masculino do que do feminino. A maioria dos dentistas relatou a presença dos pais durante o tratamento, e mais dentistas do sexo masculino utilizaram sua ajuda quando a contenção era necessária. A anestesia geral foi mais utilizada por homens do que mulheres $(\mathrm{p}=0,01)$. Um terço dos dentistas relataram sentir agressão frente ao paciente odontopediátrico. Apesar de não haver diferenças estatisticamente significantes, mais mulheres do que homens relataram sentir agressão. A maioria dos dentistas sentiram autoridade frente ao paciente odontopediátrico. Nossos achados revelam que dentistas do sexo feminino e masculino utilizam técnicas de manuseio similares frente ao tratamento odontopediátrico.

\section{REFERENCES}

1. Avgar A. Integrating work and family role. Doctoral thesis, The Hebrew University, Jerusalem, 1985.

2. U.N. 1990: The World's Women 1970-1990: Trends and Statistics. UN Special Series K.

3. Cohen LK. Women as leaders. Int Dent J 1996;46:558-564.

4. Solomon ES, Hayes MJ. Gender and the transition into practice. J Dent Educ 1995;59:836-840.

5. Waldman HB. Increasing interest in pediatric dentistry? J Dent Child 1992;59:296-300.

6. Clack GB, Head JO. Gender differences in medical graduates' assessment of their personal attributes. Med Educ 1999;33:101105.

7. Mann J, Vered Y. The status of private dentistry in Israel on the brink of the next millenium. J Isr Dent Assoc 1999;16(4):28-35.

8. Peretz B, Rozenblum A, Zadik D. Stress levels and related variables among dental students in Jerusalem, Israel. Eur J Dent Educ 1997;1:162-166. 
9. Peretz B, Ram D, Gleicher H, Mamber E. Professional education and practice arrangements: are there gender differences among paediatric dentists in Israel? Int Dent J 2000;50:390-394.

10. Wright FA, McMurray NE, Giebartowski J. Strategies used by dentists in Victoria, Australia, to manage children with anxiety or behavior problems. J Dent Child 1991;58:223-228.

11. Wright FA, Giebartowski JE, McMurray NE. A national survey of dentists' management of children with anxiety or behavior problems. Aust Dent J 1991;36:378-383.

12. Fields Jr HW, Machen JB, Murphy MG. Acceptability of various behavior management techniques relative to types of dental treatment. Pediatr Dent 1984;6:199-203.
13. Murphy MG, Fields Jr HW, Machen JB. Parental acceptance of pediatric dentistry behavior management techniques. Pediatr Dent 1984;6:193-198.

14. Peretz B, Zadik D. Parents' attitudes toward behavior management techniques during dental treatment. Pediatr Dent 1999;21:201-204.

15. Peretz B, Zadik D. Attitudes of parents toward their presence in the treatment room during dental treatment to their children. J Clin Pediat Dent 1998;23:27-30.

16. Glasrud PH. Dentists' characteristics and child behavior management techniques. J Dent Child 1984;51:337-343.

Accepted February 19, 2003 